\title{
State-owned Sewage-fed Fisheries of the East Kolkata Wetlands: An Overview
}

\author{
Dr. Suranjana Banerji \\ Assistant Professor, Department of Geography, Taki Government College
}

\section{Introduction:}

The East Kolkata Wetlands lie in the eastern fringes of Kolkata between the levee of the River Hooghly on the west and the Kulti Gong on the east (Fig 1). The wetlands spread almost equally on the two sides of the Dry Weather Flow Channel that reaches the Kulti Gong to the east. (Ghosh, D., 2005). The East Kolkata Wetlands cover an area of 12,500 hectares.

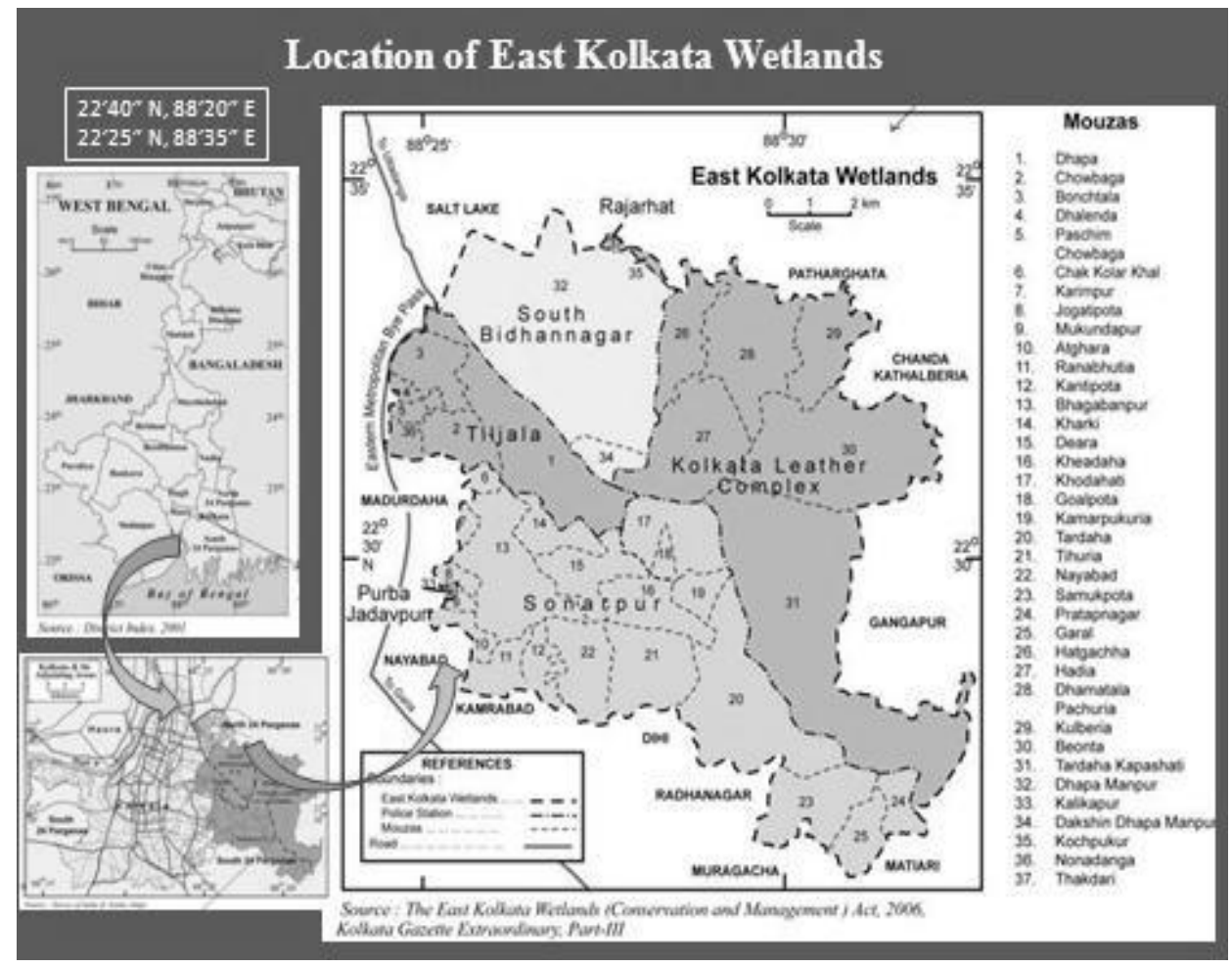

Figure 1

The area covered by the East Kolkata Wetlands comprises not only the water bodies where sewage-fed pisciculture is practiced but also agricultural land, garbage disposal site, urban and rural settlements. Sewage-fed pisciculture is an important part of the productive activities undertaken in the East Kolkata Wetlands. The uniqueness of these wetlands is that the sewage and wastewater of the city get treated in a natural way through the practice of sewage-fed pisciculture. This helps the Kolkata Municipality to save almost Rs 1,300 million per year for treating wastewater and for the fish farmers an expenditure of Rs 60 million is averted every year for buying fish feed (Ghosh, D., 2005). By using Kolkata's sewage water for pisciculture, the East Kolkata Wetlands have become a unique eco-system for natural treatment of sewage water. Majority of the sewage-fed fisheries in the East Kolkata Wetlands area are under private ownership. Though there are quite a few fishermen's cooperatives, the number of formal cooperatives is much less and the majority of cooperatives are run informally. There are only two State-owned fisheries run by the State Fisheries Development Corporation of West Bengal in the East Kolkata Wetlands area that practice sewage-fed pisciculture.

The State Fisheries Development Corporation (SFDC) Limited is a West Bengal Government Undertaking under the administrative control of the Fisheries Department. The SFDC was incorporated in March 1966 as a completely owned Government Company. It was set up with the following objectives: i) aiding, promoting, and scientifically developing fisheries and other aquatic products in West Bengal and India; 
ii) purchasing, leasing or taking rights over tanks, rivers, lakes, reservoirs, fresh/salt water fisheries etc; iii) carrying on the business of fisheries development, and other related business such as sale or export of fish and other byproducts. Besides, purchasing, leasing, hiring of boats, ships, fishing equipments etc. and, setting up of cold storage for preserving frozen fish as well as by-products like fish body oil, fish liver oil, etc. were the other aims of the Corporation (SFDC; Nalban Fisheries Project, 2004).

The management of SFDC is vested in a Board of Directors with the Minister of Fisheries, Government of West Bengal, as the Chairman. The Directors are nominated by the Minister for Fisheries. On $31^{\text {st }}$ March, 2004, for example, all the three directors were nominated by the State Government. Of them, one was the President of SFDC Employees Union, and a team of officers and technical experts assists him. The authorized capital of SFDC was rupees three crore against which the paid up capital was Rs. 2.70 crore as on $31^{\text {st }}$ March, 2004, fully subscribed by the State Government.

Table 1: Types of fish farms under SFDC

\begin{tabular}{|l|c|c|}
\hline Types of fish farms & Numbers & $\begin{array}{c}\text { Time Span } \\
\text { (Years) }\end{array}$ \\
\hline Sewage Fed Fish Farm & 2 & $1999-2004$ \\
\hline Brackish Water Fish Farm & 6 & $1999-2004$ \\
\hline Sweet Water Fish Farm & 6 & $1999-2004$ \\
\hline Reservoir Fishery & 1 & $1999-2004$ \\
\hline
\end{tabular}

At present, SFDC's activities are confined to operation of inland Fisheries. During 1999-2004, SFDC had 15 fish farms in seven districts of West Bengal. Apart from these, it also has a hatchery and a farm for producing carp fingerlings.

There are two State-owned Fisheries in the East Kolkata Wetlands. One is the Goltala SFDC and the other is Nalban SFDC. Since these fisheries are run by the State Fisheries Development Corporation, their management pattern is similar to that of other state-run corporations. Various private parties like the Sarkars of Beleghata previously owned these Fisheries. But since their ownership of land was in excess of the ceiling limit specified in the Ceiling and Regulation Act of 1976, the land was ultimately vested with the Government of West Bengal. In 1979, Nalban and Goltala came under State Fisheries Development Corporation.

The study seeks to make an estimate of the performances of the State-owned fisheries in terms of the commercial viability of the enterprises as well as their general contribution towards the conservationist goals.

\section{Methods:}

Both qualitative and quantitative methods have been followed for collection of data and analysis of the same. Qualitative research may involve a range of different methods including participant and non-participant observation, interviews in a non-standardised way so that it becomes easy to study social interaction in its innate neighbourhood and also to get a closer look at the data. Qualitative research offers a micro-level perception based on case studies or data collected from individuals and groups (Clarke, A., 2001). Quantitative research, on the other hand, adopts a numerical approach to the collection and analysis of data involving large-scale empirical studies. This type of research technique uses social survey techniques for collecting representative samples of the population spread over a vast area. Its primary concern is to construct useful factual data from which generalisations can be made (Clarke, A., 2001). Opinions of those who work on the State-owned fisheries of the East Kolkata Wetlands, were elicited by using the questionnaire method. In order to interview the members of the two-state run fisheries, permission had to be taken from the Department of Fisheries, Government of West Bengal. Fifty one people including one project-in-charge and twenty-five workers from each of the state-owned fisheries were interviewed. Audit reports from 2002 to 2010 of both the fisheries were also reviewed for analysis of the income-expenditure and fish production of the respective fisheries.

\section{Nalban State Fisheries Development Corporation:}

\section{Results:}

This Fishery is located in Dhapa Manpur of South Bidhan Nagar Police Station. The total area of the fishery is 174 hectares out of which 154 hectares are used for pisciculture. Apart from sale of fish, the Fishery also earns revenue from such entertainment facilities like boating, setting up a food court and renting out area for marriage. 155 permanent staff worked in Nalban SFDC in 2010. The project manager of the State Fisheries Development Corporation was the Project-in-Charge of this fishery and he was assisted by the Joint Project Officers. The permanent workers who worked here used to get a salary of Rs. 6000 per month initially, subsequently it would increase to 8000 per month. Their salaries were much higher than the salaries of those who worked in the privately managed sewage-fed fisheries of the East Kolkata Wetlands. Apart from the permanent workers 64 casual workers had been employed by the SFDC. 
Income Earned and Expenditure Incurred by Nalban SFDC, 2002-2010

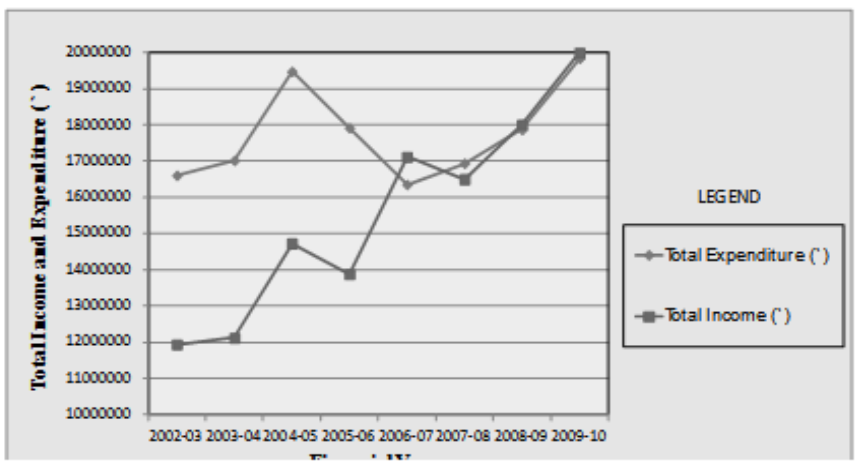

Figure 2 Source: Audit reports, 2002-2010

It is seen that from 2002-03 to 2005-06 Nalban SFDC had been running at a loss (Fig 2). It is because dredging was done during this period. Production had to be stopped when the particular fish ponds were being dredged. Arrangements were made with HIDCO (Housing Infrastructure Development Corporation) to transfer silt to Rajarhat area. Since it is a very large fishery, it took almost four years to complete the work of dredging. But during this period salaries had to be given to the permanent staffs. The net effect was the Fishery incurred huge losses during this period.

Production of Fish $(\mathrm{kg})$ of Nalban SFDC, 2002-2010

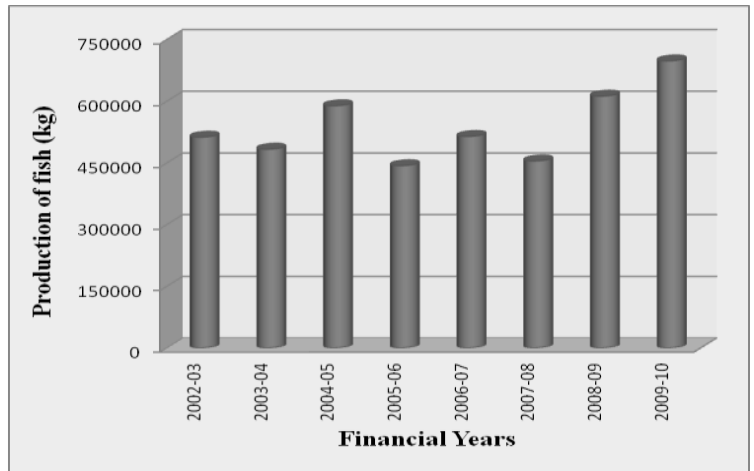

Figure 3 Source: Audit reports, 2002-2010

It is seen that production of fish was also low during this period except for the year 2004-05 because during this period dredging activities were conducted only for four months compared to seven months for other years (Fig 3). In 2006-07, the fishery made a profit of Rs. 760232.35 and production also increased. But in 2007-2008, Nalban SFDC incurred a loss as production of fish declined as a result of stoppage of work due to labour unrest. Again in 2008-09 and 2009-10, production increased and the Fishery made a marginal profit of Rs. 137463.03 in 2008-09 and Rs. 153245.89 in 2009-10. However, the yearly per hectare production of fish of Nalban SFDC was much below the desired level of 5,000-6,000 kg per hectare per year (Fig 4).

Per Hectare Production of Fish (kg) Per Year of Nalban SFDC, 2002-2010

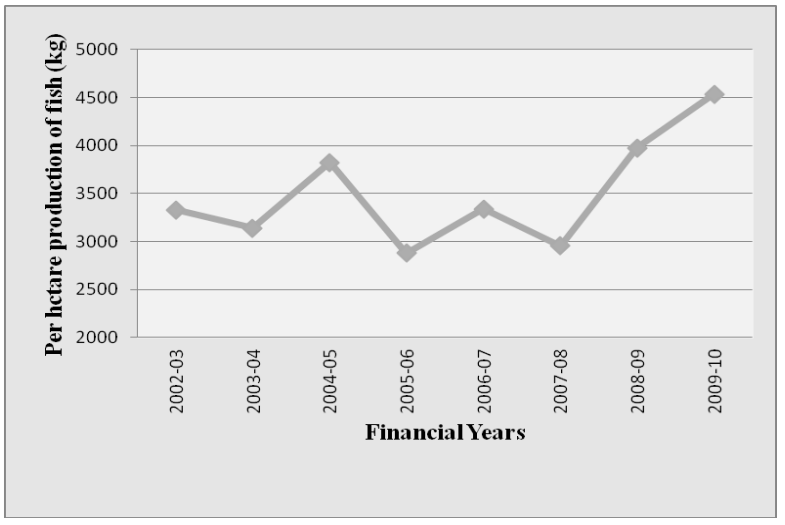

Figure 4 Source: Primary data 


\section{Problems Faced by Nalban SFDC}

Apart from labour trouble as mentioned by the project manager, another major problem that is affecting production of Nalban SFDC is decline in availability of sewage water. It gets sewage water only twice a week from the Dhapa Pumping Station. As a result cost incurred for buying fish feed is very high. The Nalban Fishery has been supplementing its income from pisciculture by promoting tourism and converting it partly into an amusement park. But environmentalists point out that boating at times causes injury to the fishes and in the process fishes often die. They further mentioned that use of halogen lights and generators also cause disturbance for the fishes.

Income Earned and Expenditure Incurred by Goltala SFDC 2002-2010

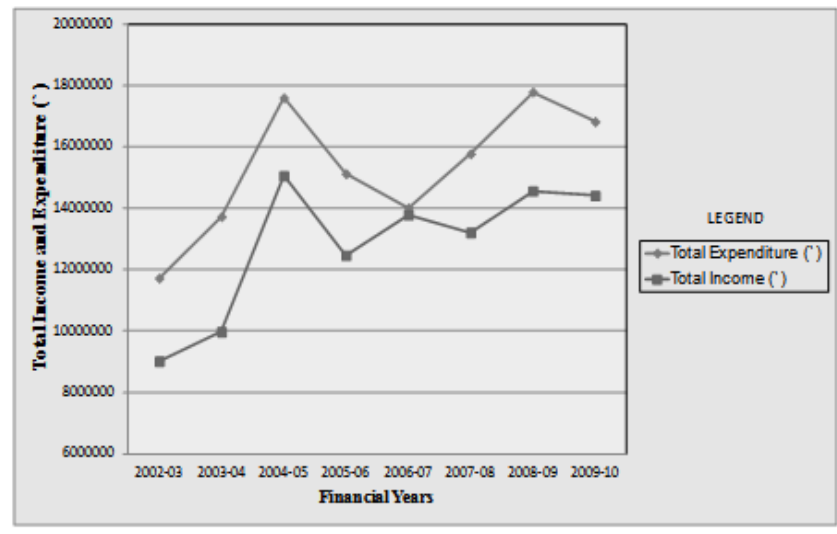

Figure 5

Source: Audit reports, 2002-2010

\section{Goltala State Fisheries Development Corporation}

This Fishery is located in Dhapa Manpur of South Bidhan Nagar Police Station. The total area of the fishery is 90.32 hectares out of which 70.25 hectares are used for pisciculture. Revenue earned by Goltala SFDC is mainly from sale of fish. They also earn some revenue by selling green coconuts which is grown within their compound. 100 permanent staff worked in Goltala SFDC in 2010. Just like Nalban SFDC, the project manager of the State Fisheries Development Corporation is the project-in-charge of this Fishery and he was assisted by the joint project officers. The permanent workers who worked here got a salary of Rs. 6000 per month initially and then it would rise to Rs. 8000 per month. Apart from the permanent workers, there were 110 share catchers for catching fish employed as casual labourers on a temporary basis. The Goltala SFDC was running at a loss from 2002-2010 (Fig 5). Fig 6 shows the yearly per hectare production of fish from 2002 to 2010. Compared to Nalban its per hectare production was much better and between 2004-07 and 2008-10, it achieved the desired production level. During 2007-08, production of fish declined as a result of stoppage of work due to labour trouble.

Per Hectare Production of Fish (kg) Per Year of

Goltala SFDC, 2002-2010

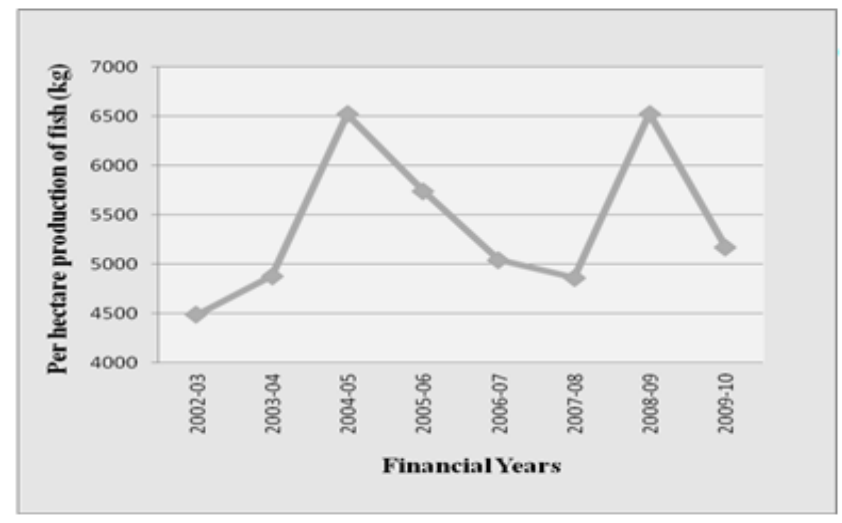

Figure 6

Source: Primary data 
It is seen that during 2004-05 and 2008-09 total production of fish was more than 5.5 lakh $\mathrm{kgs}$, nevertheless the fishery was running at a loss (Fig 7). This was because, as pointed out by the project-in-charge, the total number of workers employed in Goltala SFDC was much higher than what was required. But since this employment is provided by the Government the project-in-charge did not have the authority to reduce the number of workers. Secondly, due to its location it is very difficult to undertake dredging activities here and the depth of one-third of the total area under pisciculture is 3 feet and the rest is only two to two and a half feet. So to augment production within a relatively small area high quality fish feed and fish fingerlings were bought, thus adding up the production cost. Fortunately, this fishery does not have the problem of availability of sewage water.

Production of Fish (kg) of Goltala SFDC, 2002-2010

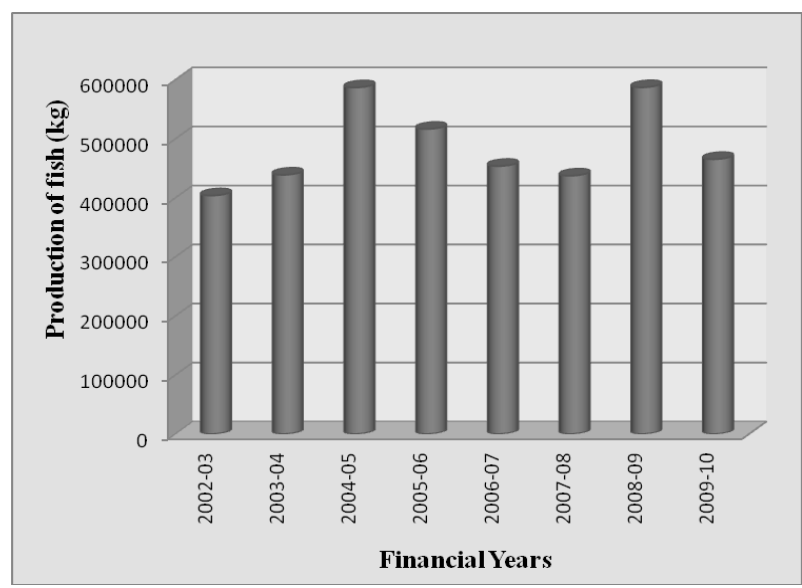

Figure 7 Source: Audit reports, 2002-2010

Goltala Fishery, in terms of output per hectare of production, was the best; nevertheless it was running at a loss for the entire period under review. It may sound strange, but the reasons are not far to seek.

\section{Problems Faced by Goltala SFDC}

First and foremost, Goltala Fishery became an agency of the government for providing employment, rather than a profit making concern which could give employment to people and also earn some profit to be ploughed back to the project for its improvement. Indeed, as the project-in-charge pointed out, it employed more people than was needed, thereby increasing the cost of production per hectare. Secondly, although the SFDC employees earned wages that were much higher than those of their counterparts working in privately managed fisheries, neither the Goltala Fishery nor the Nalban Fishery was free from labour trouble. In private conversations, the project-in-charge for the Goltala SFDC squarely blamed the workers for this. Apart from these, the Goltala Fishery also had the problem of dredging; due to its location, it was difficult to undertake dredging activities here. Last, but not the least, because of the poor economic background of the people living in the surrounding area the fishery was also severely affected by the problem of poaching.

\section{Perceptions of Workers of Nalban and Goltala SFDCs in the East Kolkata Wetlands about the Desirability of filling up of Sewage-fed Fisheries for Development Activities}

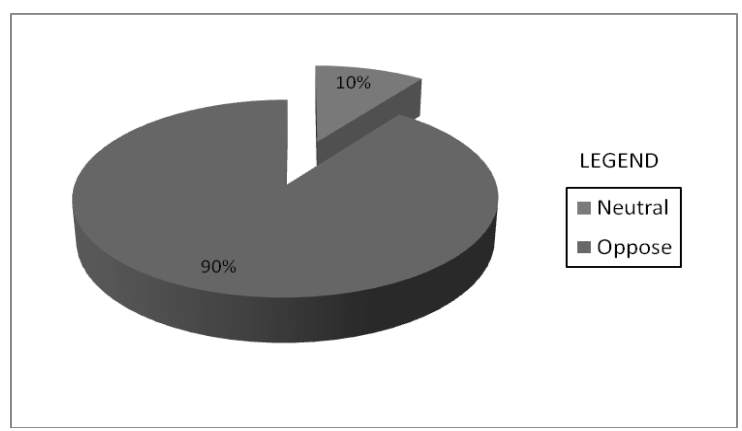

Figure 8 Source: Primary data 


\section{Perceptions of Workers of Nalban and Goltala SFDCs in the East Kolkata Wetlands about the Desirability of filling up of Sewage-fed Fisheries for Development Activities}

Most of the permanent workers working in the Nalban and Goltala SFDCs in the East Kolkata Wetlands area were initially unwilling to discuss the issue since they thought that their interests were protected as they work in state-owned fisheries. However, when persuaded to discuss the issue broadly from the perspective of pisciculturists working in sewage-fed fisheries in the East Kolkata Wetlands area, 90 per cent opposed the idea as could be seen (Fig 8) on the ground that this would adversely affect pisciculture and livelihood of those dependent on pisciculture. 10 per cent were non-committal in their views.

\section{Perception of Workers of Nalban and Goltala SFDCs in the East Kolkata Wetlands about Good Prospect of its Fisheries}

80 per cent of the permanent workers seemed to be quite optimistic about the future prospects of the survival of the fisheries run by the SFDC in the East Kolkata Wetlands area, since these were under the direct control of a state-owned corporation (Fig 9). About 20 per cent of the workers, however had a different view and thought that if the fisheries were to be run continuously as loosing concerns, the government in future may decide to hand them over to some private player, or decide to run them on the basis of private-public partnership which may put a question mark on the present structure of these fisheries.

\section{Perception of Workers of Nalban and Goltala SFDCs in the East Kolkata Wetlands about Good Prospect of its Fisheries}

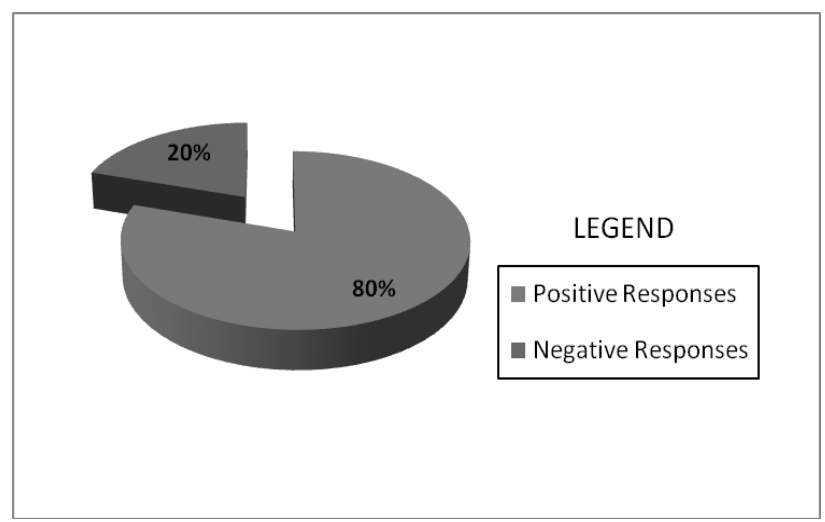

Figure 9 Source: Primary data

\section{Discussions and Conclusion:}

Sewage-fed fisheries are playing an important role in the preservation of the East Kolkata Wetlands. It is important to note here that both Goltala and Nalban fisheries are facing certain problems such as the problem of dredging, insufficient supply of sewage water in the fisheries and a decline in the quality of nutrients in the sewage water, escalating costs of production in terms of input costs and rising wages/salaries, and, last but not the least, the problem of labour unrest and poaching.

The Goltala Fishery, one of the largest in the area and having the largest man-power resources had been running at a loss during the years under review though in terms of production of fish per hectare the Goltala SFDC is certainly better. Perhaps this was due to its large administrative set-up and the lack of opportunities on the part of the managers to initiate such measures (for example, reduction in the number of employees) which would make this fishery economically viable. Moreover, the permanent staffs in the Goltala SFDC are all government employees and enjoy the benefits of government service, although they do not necessarily take such initiatives which would contribute to the overall improvement in the financial health of the fishery concerned. The Nalban SFDC, although larger in size than the Goltala SFDC, had a rate of fish production per hectare much lower than that of the Goltala SFDC. It had been running at a loss for most of the time although it did try to augment its income through such other activities as facilities for boating in the waterbodies, setting up food kiosks in the areas which are not covered by the waterbodies and by letting out space for social gatherings and entertainment, which according to the environmentalists are not favourable for the fish. Despite all these activities, it could earn only a marginal profit during the years 2006-07, 2008-09 and 2009-10, while it incurred losses during rest of the years under review. The reasons for the less than satisfactory performance of the Nalban SFDC are similar to those of the Goltala SFDC.

In spite of the unsatisfactory performance of the state-owned fisheries, majority of the pisciculturists working in the Nalban and Goltala SFDCs are against the idea of filling up of sewage-fed fisheries for any kind 
of development activities even if they are given a handsome compensation. Most of them who have been interviewed are still optimistic about the future prospects of the state owned sewage-fed fisheries in the East Kolkata Wetlands area and expect the government to take some ameliorative measures to enable the fisheries to tide over the difficulties they are facing. They also pointed out that the government may also take the initiative in imparting scientific education to the pisciculturists for improvements in the quality and quantity of fish production.

Last, but not the least, the pisciculturists themselves have to take certain initiatives for preservation and sustainable development of the sewage-fed fisheries. In the final analysis, it is their commitments to preserve the fisheries that will be most important in the preservation of the East Kolkata Wetlands.

\section{References}

[1] Chattopadhyay, K., 2001. Environmental Conservation and Valuation of East Calcutta Wetlands. Mumbai: Indira Gandhi Institute of Development Research.

[2] Clarke, A., 2001. Research and the Policy Making Process. In N. Gilbert, ed. Researching Social Life. $2^{\text {nd }}$ edition. New Delhi: Sage, 2001.

[3] Ghosh, D., 2002. Ecosystem Management. In S. R. Basu, ed. Changing Environmental Scenario of the Indian Subcontinent. Kolkata: acb publications, 2002

[4] Ghosh, D., 2005. Ecology and Traditional Wetland Practice: Lessons from Wastewater Utilisation in the East Calcutta Wetlands. Kolkata: Worldview.

[5] Kundu, N., 2002. Management of Wetlands: A Case Study of West Bengal. In S. R. Basu, ed. Changing Environmental Scenario of the Indian Subcontinent. Kolkata: acb publications, 2002.

[6] Mukherjee, M. \& Chattopadhyay, K. ed., 2002. Kolkata - The City Of Wetlands: uncared resource, unrecognized beauty and unexplained truth. Kolkata: Department of Fisheries, Govt. of West Bengal in collaboration with Ministry of Agriculture, Govt. of India. 